Павлова Олена, доктор економічних наук, професор, Східносвропейський національний університет імені Лесі Українки, завідувач кафедри аналітичної економіки та природокористування, м. Луцьк; ORCID ID: 0000-0002-8696-5641, e-mail: pavlova.olena@eenu.edu.ua

Павлов Костянтин, доктор економічних наук, професор, Східносвропейський національний університет імені Лесі Українки, професор кафедри аналітичної економіки та природокористування; м. Луцьк; ORCID ID: 0000-0003-2583-9593, e-mail: pavlovkv@icloud.com

Купчак Володимир, доктор економічних наук, професор, Східносвропейський національний університет імені Лесі Українки, професор кафедри аналітичної економіки та природокористування, м. Луцьк;

https://doi.org/10.29038/2411-4014-2020-02-161-167 e-mail: kupchak@me.com

\title{
РЕФОРМУВАННЯ ЖИТЛОВО-КОМУНАЛЬНОЇ СФЕРИ В МІСЬКИХ АГЛОМЕРАЦІЯХ ЗА УМОВ ДЕЦЕНТРАЛІЗАЦІї
}

В статті розглянуто теоретичні та практичні проблеми розвитку житлово-комунальної сфери міських агломерацій в умовах децентралізації. Деталізовано суть та значення поняття «децентралізації», конкретизовано тлумачення наукових видань з цього приводу. Досліджено етапи та особливості формування міських агломерацій житлово-комунального господарства в регіонах України. Охарактеризовано основні риси та типи пануючих міських агломерацій в Україні, а також з'ясовано основні перепони, які перешкоджають їх успішній реалізації в господарський устрій регіону; відмічаються специфіка створення міських агломерацій провідними країнами світу. Проаналізовано діюче нормативно-правове забезпечення дієвості міського агломерації. Обгрунтовується, що досвід реформування житлово-комунальної сфери кожної 3 країн $\epsilon$ унікальним та віддзеркалює специфіку окремо взятої країни, що призводить до неефективності запровадження зарубіжного досвіду, без врахування власного економічного, соціального та територіального потенціалу. Досліджено агломераційний ефект, який отримується шляхом ефекту від масштабу, збільшення відносного показника наданих послуг на одиницю площі, кількісне та якісне зростання обслуговування за рахунок ефективності науково-дослідних установ, навчальних закладів та дії впливу соціальної інфраструктури. Сформовано пріоритетні напрями проникнення інноваційних підходів та методів в житлово-комунальну сферу міського агломеративного регіонального угрупування. Доведено, що динамічність процесів реформування житлово-комунальної сфери міських агломерацій залежить від ефективності використання механізмів державно-приватного капіталу задля реалізації важливих інфраструктурних об’єктів.

Ключові слова: міська агломерація, житлово-комунальна сфера, децентралізація, інфраструктура, комунікація, інвестиційний капітал, енергоефективність.

Павлова Елена, доктор экономических наук, профессор, Восточноевропейского национального университета имени Леси Украинки, заведующий кафедрой аналитической экономики и природопользования, г. Луцк

Павлов Константин, доктор экономических наук, профессор,

Восточноевропейского национального университета имени Леси Украинки, профессор кафедры аналитической экономики и природопользования, 
Купчак Владимир доктор экономических наук, профессор, Восточноевропейского национального университета имени Леси Украинки, профессор кафедры аналитической экономики и природопользования,

\title{
РЕФОРМИРОВАНИЕ ЖИЛИЩНО-КОММУНАЛЬНОГО СЕКТОРА ГОРОДСКИХ АГЛОМЕРАЦИЙ В УСЛОВИЯХ ДЕЦЕНТРИЗАЦИИ
}

\begin{abstract}
В статье рассматриваются теоретические и практические проблемы развития жилищно-коммунальной сферы городских агломерций в условиях децентрализации. Суть и смысл понятия «децентрализация» детализированы, интерпретация научных публикаций по этому вопросу забетонирована. Изучаются этапы и особенности формирования городских агломерций жилищно-коммунального хозяйства в регионах Украины. Описаны основные особенности и виды преобладающих городских агломерций в Украине, а также основные препятствия, препятствующие их успешному внедрению в экономическую структуру региона; Отмечена специфика создания городских агломераций ведущих стран мира. Анализируется эффективное нормативноправовое обеспечение эффективности городской агломерации. Обоснованность того, что опыт реформирования жилищно-коммунального сектора каждой страны уникален и отражает специфику конкретного государства, что приводит к неэффективности внедрения зарубежного опыта без учета собственной экономической, Социальный и территориальный потенциал. Эффект агломерации, полученный эффектом от шкалы, увеличением относительного уровня оказываемых услуг на единицу площади, количественным и качественным ростом обслуживания за счет эффективности научно-исследовательских институтов, образовательных и действия социальной инфраструктуры. Формируются приоритетные направления проникновения инновационных подходов и методов в жилищно-коммунальную сферу городской агломеративной региональной группировки. Доказано, что динамизм процессов реформирования жилищнокоммунальной сферы городских агломераций зависит от эффективности механизмов государственно-частного капитала для реализации важных инфраструктурных объектов.
\end{abstract}

Ключевые слова: городская агломерация, жилищно-коммунальная сфера, децентрализация, инфраструктура, связь, инвестиционный капитал, энергоэффективность.

Pavlova Olena,

Doctor of Economic Sciences, Full Professor,

Lesya Ukrainka Eastern European National University, Head of the Chair of Analytical Economics and Natural Resources Management, Luck

Pavlov Kostiantyn, Doctor of Economic Sciences, Professor, Lesya Ukrainka Eastern European National University, Professor of the Chair of Analytical Economics and Natural Resources Management, Luck

Kupchak Volodymyr, Doctor of Economic Sciences, Professor, Lesya Ukrainka Eastern European National University, Professor of the Chair of Analytical Economics and Natural Resources Management,

Luck

\section{REFORMING OF THE HOUSING AND COMMUNAL SPHERE IN URBAN AGGLOMERATIONS UNDER DECENTRALISATION CONDITIONS}

Introduction. The article considers theoretical and practical problems of development of housing and communal sphere of urban agglomerations in the conditions of decentralisation. The essence and meaning of the concept of "decentralisation" are detailed, the interpretation of scientific publications on this issue is concretedly. The stages and 
peculiarities of the formation of urban agglomerations of housing and communal services in the regions of Ukraine are investigated. The main features and types of the prevailing urban agglomerations in Ukraine, as well as the main obstacles which prevent their successful implementation into the economic structure of the region are described; The specifics of creating urban agglomerations leading countries of the world are noted. An effective normative-legal provision of the effectiveness of urban agglomeration is analyzed. The of substantiated that the experience of reforming the housing and communal sector of each country is unique and reflects the specifics of a particular state, which leads to the inefficiency of the introduction of foreign experience, without taking into account its own economic, Social and territorial potential. The agglomeration effect, obtained by the effect from the scale, an increase of the relative rate of services rendered per unit area, quantitative and qualitative growth of servicing due to the efficiency of research institutions, educational and actions of the social infrastructure. Priority directions of penetration of innovative approaches and methods in housing-communal sphere of urban agglomerative regional grouping are formed. It is proved that dynamism of the processes of reforming of the housing and communal sphere of urban agglomerations depends on efficiency of public-private capital mechanisms for realization of important infrastructure objects.

The purpose of the articl. The substantiation of the reform approaches to the development of urban agglomerations in the conditions of decentralisation by forming the agglomeration effect at enterprises for population livelihoods.

Results. In this aspect, it is important to obtain the state financial support of the introduction of innovative mechanisms and facilitate the modernization of the city engineering infrastructure based on modern technological solutions. Continuation of the process of financing reforms in terms of decentralization and energy efficiency is still a budget priority for the year 2020. However, given the chronic deficit of the state budget, the issues of the innovation and investment source of infrastructure objects leads to the search for extra-budgetary cells, among which the key place is given to international financial organizations.

Conclusions. Therefore, due to the agglomeration effect on housing and communal economy the important role is given to measures specialized research institutions that function in the comprehensive economic and legal analysis and sociological research features Functioning of the individual local agglomeration, as well as monitoring the State and development trends of housing and communal services including the effectiveness of public-private capital mechanisms for the implementation of important infrastructure facilities.

Key words: Urban agglomeration, housing and communal sphere, decentralization, infrastructure, communication, investment capital, energy efficiency.

Постановка проблеми та її значення. Вагоме значення сфери життєзабезпечення в економічному та соціальному розвитку міста, регіону та країни загострює проблему житловокомунального господарства. Однак щороку починаючи 32014 р. статистична інформація про функціонування ЖКГ свідчить про динаміку збитків та фінансово-економічного колапсу підприємств. Виходячи із існуючої практики останніми роками та достатнім теоретичним переконанням, розвиток міських агломерацій є дієвим важелем та інструментом стабілізації ситуації та антикризовим методом підвищення ефективності господарювання підприємств сфери ЖКГ. В основному це відбувається за рахунок комунікації та співробітництва територіальних громад, влади, бізнесових кіл, а також їхнє спільне бажання інтегруватися та поєднувати спільні зусилля в економічному, соціальному та правовому аспектах. В той же час, деценралізаційні моменти, які не так давно застосовуються в міських осередках мають вплив на створення організаційно-економічних передумов подальшої демократизації територіального господарювання суб'єктів .

Аналіз останніх досліджень і публікацій. Значний внесок у формування етапів дослідження різноманітних проблемних питань ЖКГ зроблено вченими: С. Градобоєвою, А. Бабак, С. Бочаровим, М. Мельниковою, А. Омельченко. Різнобічно міські агломерації в контексті децентралізації досліджувалися зарубіжними та вітчизняними вченими та дослідниками: В. Міхненком, I. Архипенком, I. Іртіщевою та іншими. Проте існуючі проблеми теоретико-практичного характеру в ЖКГ та в організаційному сенсі міських агломерацій виникають здебільшого через відсутність досвіду їх вирішення в умовах децентралізації, також практики інших суб'єктів їх реалізовувати на регіональному рівні та систематизації накопичених уявлень. Все це дозволяє здійснювати пошук альтернативних шляхів для запровадження реформування житлово-комунальної сфери міських агломерацій.

Метою статті є: обгрунтування реформаторських підходів до розвитку міських агломерацій в умовах децентралізації шляхом формування агломераційного ефекту на підприємствах по життєзабезпеченню населення. 
Викладення основного матеріалу та обгрунтування отриманих результатів дослідження. Будь-яка міська агломерація включає в себе транспортну, комунальну та промислові інфраструктурні комунікації. В свою чергу комунальна інфраструктура $є$ необхідною складовою багатьох інших міст та територіальних громад [2]. Тому інвестиційна модернізація комунальної інфраструктури розвитку ЖКГ міських агломерацій $є$ одним з найважливіших завдань регіональної економічної політики. Це можливо реалізувати шляхом зацікавленості приватного сектора в протіканні інвестиційних проектів інфраструктурного забезпечення міських агломерацій. Тут спрацьовує так званий “агломераційний ефект”, який отримується шляхом ефекту від масштабу, збільшення відносного показника наданих послуг на одиницю площі, кількісне та якісне зростання обслуговування, за рахунок науководослідних установ, вищих учбових закладів та соціальної інфраструктури. Вперше практика створення великих агломерацій відбулася на Донбасі та промисловому Придністров’ї. Без сумніву, майже всі інші міста України являють собою значні урбанізаційні центри, формуючи так званий “агломераційний ефект", чинячи вплив на соціальну та економічну сторони життя регіону, але ще й досі не мають правового статусу та детальної статистичної результативності. На разі термін "міська агломерація" введено до практичного обігу Постановою Кабінету Міністрів України від 17 березня 2000 року №521 "Про основні напрямки забезпечення комплексного розвитку малих монофункціональних міст". [5]. В цьому документі міські агломерації розглядаються як рушій модернізації інфраструктурного забезпечення самих міст.

Міські агломерації дедалі більше стають ключовим аргументом для відтворення сталого розвитку країни в напрямі покращення життя населення, сприяння потрібної конкуруючої атмосфери для малого та середнього бізнесу. Власне, потрібні інноваційні шляхи розвитку економіки є сутністю наукових, освітніх, трудових та культурних зв’язків міських агломерацій формуючи джерела інвестиційного капіталу та неухильність та багатовекторність розвитку продуктивних сил. Серед особливих рис, які доповнюють цінність міських агломерацій, слід розуміти: організацію простору: глобалізаційні процеси, диверсифікаційну політику, економічну інтеграцію та інформатизованість регіону [8].

- організація простору пов'язана 3 правильною регіональною політикою щодо підвищення конкурентоспроможності ефекту об'єднань міських агломерацій в умовах глобалізаційних процесів, де за основу слід брати: збалансовану міську систему взаємовідносин між містом та селом, доступність та зручність інфраструктури ціллю організації простору є систематизація зусиль у різних напрямах діяльності регіонів-метрополій та прилеглих міських транспортних центрів, планування мережевих підприємств, тощо;

- глобалізаційний процес - $є$ загальнодоступним процесом переплітання зв'язків міжнародної інтеграції через рух товарів та послуг, міграції робочої сили, транспорту, технологій та руху капіталу, шляхом глобалізації можна досягти важливих досягнень у будь-якій країні для інших;

- диверсифікаційна політика формує в собі стратегію виходу з усталених форм та видів діяльності в передбаченні пошуку нових ринків збуту, маніпулювання оновлених фінансових джерел, уникнення ймовірних ризиків. Для міських агломерацій диверсифікаційна політика спрямована на відтворення диверсифікованого рівня освіти, культури, традиції, господарського устрою раціональності поведінки регіону;

- екологічна інтеграція покращує економічну ситуацію соціуму шляхом турботи про навколишню ситуацію. Це проявляється в екологізації виробництва, екологічно-чистого ведення господарства, проведення вірної екологічної політики, тощо;

- інформатизованість регіону охоплює сутність взаємоузгоджених організаційних, політичних, соціально-економічних, науково-технічних та виробничих потреб до інформатизованого потенціалу достатнього для їх реалізації. Це відбувається шляхом широкомасштабного використання ITтехнологій у різних напрямках життя регіону.

Предметом закону України "Про міські агломерації" [6] визначено належність певних умов існування міської агломерації:

- для формування міської агломерації достатньо три територіальних громади разом 3 осередком агломерації;

- чисельність населення міської агломерації не менше 100 тисяч осіб; 
- територіальною межею агломерації є нерозривні кордони зовнішньої юрисдикції рад територіальних громад, які формують агломерацію.

На разі прийняття даного Закону дозволить спрямувати потенціал та переваги великих міст для ефективності розвитку регіонів та держави в цілому. Впорядкування міської агломерації не спричиняє припинення повноважень органів місцевого самоврядування та статутної зміни населених пунктів.

Сьогодні Україна характеризує два типи агломерацій: моноцентричні агломерації (Київ, Харків, Львів) ті поліцентричні (Донецьк, Луганськ). Зазвичай найменування міської агломерації походить від назви осередку агломерації хоча й може включати назву другого населеного пункту, де різниця в кількості населення не перевищує 25\% [3]. Однак, функціонування агломерацій тягне за собою ряд труднощів та відсутність злагодженого механізму оптимального поєднання можливостей та інтересів зацікавлених суб'єктів, громадськість, владу та населення. Основними гальмівними чинниками стимулювання розвитку міських агломерацій є: відсутність єдиної стратегії розвитку територій та координації органів місцевого самоврядування адміністративно-територіальних одиниць агломерації, відсутність інформатизованості про статистичні процеси в середині агломерації, неузгодженість законодавчого тлумачення терміну “агломерація".

Активізація поняття децентралізація в процесах розвитку місцевого агломераційного угрупування потребує свого сутнісного уточнення, зокрема енциклопедичний словник тлумачить це поняття різь призму передачі повноваження функцій управління від головних органів дії до місцевих ланок виконавчої дії, коло повноважень яких є значно звуженим [9]. Словник сучасної української мови, розглядає децентралізацію, як систему управління, за якої функції центральної влади виконуватимуть місцеві органи управління. Займаючи вагоме місце в забезпеченні конституційної стабільності України та оптимізуючи територіально-правові основи функціонування державності, децентралізація, як процес посідала чільне місце в трансформаційній діяльності держави. В законодавчому полі, це підкріплюється рядом законопроектів: Закон «Про місцеві Ради народних депутатів і місцеве самоврядування»1990 року, «Про представника президента України», «Про місцеві Ради народних депутатів і регіональне самоврядування ». Слід відмітити, що в цілому децентралізація є однієї з форм демократії, що дозволяє зберегти єдність державності, інституційне розширення місцевого самоврядування, пожвавлення трудового потенціалу населення 3 забезпеченням власних потреб населення регіону. Водночас, децентралізація є складним процесом, який охоплює усі сфери: територіально-адміністративну, організаційно-установчу, органів місцевого самоврядування, бюджетної та податкової системи, земельних відносин, соціального та гуманітарного напрямів. Досвід розвинених зарубіжних країн свідчить про позитивний ефект від децентралізації здебільшого за умов докорінних реформацій в суспільно-побутовому устрою країни, та при необхідності значного підвищення потенціалу місцевих органів самоврядування. Процес розвитку місцевих агломерацій житлово-комунального господарства за умов децентралізації покликаний, сьогодні :

-відмежовувати права та повноваження різних голок влади задля формування міцних правових, соціальних та демократичних засад, задля дотримання балансу інтересів в системі публічних відносин;

- впровадження в дію системної регіональної політики, задля забезпечення ефективності регіонального розвитку,

- дотримання принципу субсидіарності, який змушений буде узгоджувати інтереси органів виконавчої влади та органами місцевого самоврядування;

- впровадження адміністративно-територіальної реформи в умовах унітарності та цілісності;

-формування механізму адміністративної відповідальності посадових осіб місцевого самоврядування.

Загалом, децентралізація житлово-комунального господарства місцевих агломерацій за умови впровадження ряду заходів сприятиме побудові розвиненої, ефективної, демократичної держави, 3 необхідним спектром соціальних, організаційних, побутових та суспільних послуг.

Гостра конкуренція міст України змушує активізувати взаємозв'язок між інвестиційними залученнями та пошуком резервів ті модернізацією житлово-комунального господарства, яке опосередковано чинить вплив на конкурентоспроможність усього регіону. Зрозуміло, що без 
відповідного розвитку інфраструктурного забезпечення, не відбудеться формування потенціалу міських агломерацій. Важливим вектором розвитку житлово-комунального господарства містких агломерацій $\epsilon$ :

- здійснення комерційного обліку теплової енергії; води та водовідведення;

- запровадження осучаснених форм господарювання ЖКГ, які засновані на раціональності та прогресивному європейському досвіді;

- зниження витратної частини, яка формує собівартість послуг ЖКГ;

- Оптимізація тепло та водопостачання при передачі електроресурсів шляхом зменшення енергомісткості та ресурсомісткості, реалізація відповідних інноваційно-інвестиційних проектів із залученням приватного капіталу в інфраструктурному забезпеченні [1].

Однак підприємства сфери життєзабезпеченості не спроможні реалізувати виділені вектори виходячи 3 тих обставин, які на сьогодні склалися та $є$ базисом для їх діяльності. Найбільш реалістичними з них є такі:

- різні форми власності;

- відсутність прав на інтелектуальну приналежність інженерних винаходів;

- значна замонополізованість підприємств відповідної галузі;

- фіксація доходної частини державним або регіональним органом влади;

- відсутність реакції споживачів;

- значна енергомісткість виробництва та надання послуг житлово-комунальної сфери.

Причинами появи перелічених обставин є:

- законодавство України (не диференціює можливість надання житлово-комунальних послуг залежно від форми власності та сфери забезпечення);

- обмеження умов привласнення (основні інженерні комунікації та винаходи є частиною комунальної або загальнодержавної власності);

- централізація та монополізм (панування мережевих економік та споруд комунальної інфраструктури прив'язує споживача та зумовлює зменшення ефективності надання останніми певних послуг;

- контроль (шляхом регіонального регулювання ціноутворення, тарифоутворення);

- відсутність конкуруючого ринку та хронічний цілком нееластичний попит споживача;

- централізована залежність від енергоринкові кон'юнктури в тому числі і від національно встановленої тарифної політики;

Виходячи 3 цих обставин $є$ зрозумілим, що дієвим та важливим заходом здійснення реформування сфери ЖКГ буде впровадження інноваційно-інвестиційної політики. На разі мова піде про потрібні інфраструктурні проекти, які засновані на об'єднанні зусиль між територіальними громадами. Наше законодавство розглядає цей тандем у формі співробітництва та партнерства за умови дотримання принципів добровільності та обопільності взаємних стосунків; часовості та тривалості до свого завершення взаємовигоди, обліку ресурсів та можливості делегування повноважень [7].

В цьому аспекті $є$ важливим отримання державної фінансової підтримки впровадження інноваційних механізмів та сприяння процесу модернізації міської інженерної інфраструктури базуючись на сучасних технологічних рішеннях. Продовження процесу фінансування реформ за умов децентралізації та енергоефективності є і надалі бюджетним пріоритетом на 2020 рік. Однак 3 огляду на хронічний дефіцит державного бюджету, питання інноваційно-інвестиційного джерела інфраструктурних об'єктів призводить до пошуку позабюджетних осередків, серед яких ключове місце відводиться міжнародним фінансовим організаціям [4].

Відносно цього, з лютого 2016 року Верховна Рада України ратифікувала Фінансову угоду (проєкт "Програма розвитку муніципальної інфраструктури України”) між Україною та Європейським інвестиційним банком. Згідно даної Угоди, Європейським інвестиційним банком було надано кредит в обсязі 400 млн. Євро задля реалізації державних інфраструктурних проектів міських агломерацій середніх та великих міст. 
Висновки і перспективи подальших досліджень. Отже, з огляду на агломераційний ефект на житлово-комунальне господарство важлива роль відводиться заходам профільних науково-дослідних установ, які функціонують на всебічному економіко-правовому аналізі та соціологічного дослідження особливостей функціонування окремо взятої місцевої агломерації, а також моніторингу стану та тенденцій розвитку ЖКГ в тому числі що стосується ефективності використання механізмів державно-приватного капіталу задля реалізації важливих інфраструктурних об’єктів.

\section{Джерела та література}

1. Бабак А. В. Особливості визначення регуляторної бази активів для цілей ціноутворення в сфері теплопостачання України. Економіка Украӥни. 2012. №12. С. 51-64.

2. Богачов С. В., Мельникова М. В., Устименко В. А. Економіко-правові проблеми розвитку великих міст та агломерацій в Україні: монографія. Харків. Видавництво "НТМТ”. 2015. 247 с.

3. Варланов Ю., Варланов О. Агломерація в Україні та економічне зростання. Наукові праиі Чорноморського державного університету імені Петра Могили. Серія "Економіка". 2010. т. 133. Вип 20. С. 116-124.

4. Мельникова М. В., Градобоєва С. С. Розвиток сфери життєзабезпечення в міських агломераціях. Інноваційно-інвестиційні аспекти. Мукачівський держсавний університет. Випуск №2. 2016.

5. Постанова КМУ «Про Основні напрями забезпечення комплексного розвитку малих монофункціональних міст».URL: https://zakon.rada.gov.ua/laws/show/521-2000-п.

6. Про міські агломерації: проект Закону України від 17 липня 2017 №6743. Головний правовий портал України. URL: http://search.ligazakon.ua/__doc2.nsf/link1/GH57B00A.html (дата звернення: 25.06.2019)

7. Розвиток міжмуніципального співробітництва: вітчизняний та зарубіжний досвід. Під редакцією Голкованова. К.: Крамар. 2011.361 с.

8. Степаненко А.В., Онищенко А. А. Міські агломерації, як форми сучасного світового процесу глобалізації. Серія “Економіка та підприємництво”. 2019 р. №3 (108).

9. Юридична енциклопедія : в 6т. / ред. колегія Ю. С. Шемшученко (відп.ред.) [та ін.]. - Київ: Укр. енциклопедія., 1999. - Т.2: Д-Й. - 744 с.

10. Pavlov K., Pavlova O. \& Kupchak V. (2019). Integral Indicators Based on Competitiveness Capacity Characteristics of Regional Real Estate Markets of Ukraine. Journal of Competitiveness. №11(3). 87-108. https://doi.org/10.7441/joc.2019.03.06.

\section{References}

1. Babak, A. (2012). Osoblyvosti vyznachennya rehulyatornoyi bazy aktyviv dlya tsiley tsinoutvorennya v sferi teplopostachannya Ukrayiny [Features definition of regulatory base of assets for pricing purposes in the sphere of heat supply of Ukraine]. Ekonomika Ukrayiny - Economy of Ukraine, 7 [in Ukrainian].

2. Bogachov, S.V., Melnikova, M.V., Ustimenko, V.A. (2015). Ekonomiko-pravovi problemy rozvytku velykykh mist ta ahlomeratsiy $v$ Ukrayini [Economic and legal problems of development of big cities and agglomerations in Ukraine]. Kharkiv. NTMT Publishing House. [in Ukrainian].

3. Varlanov, Y., Varlanov, O. (2010). Ahlomeratsiya v Ukrayini ta ekonomichne zrostannya. [Agglomeration in Ukraine and Economic Growth]. Seriya "Ekonomika"- Economy series, 20, [in Ukrainian].

4. Melnikova, M.V., Gradoboeva, E.S. (2016). Rozvytok sfery zhyttyezabezpechennya $v$ mis'kykh ahlomeratsiyakh. Innovatsiyno-investytsiyni aspekty [Development of the sphere of life support in urban agglomerations. Innovation and investment aspects]. Mukachevo State University, 2 [in Ukrainian].

5. CMU Resolution «Pro Osnovni napryamy zabezpechennya kompleksnoho rozvytku malykh monofunktsional'nykh mist» [On Main Directions for Integrated Development of Small Monofunctional Cities]. (n.d.). zakon.rada.gov.ua. Retrieved from http://zakon.rada.gov.ua/ laws/show/521-2000-п [in Ukrainian].

6. Draft Law of Ukraine «Pro mis'ki ahlomeratsiyi» [On urban agglomerations].(n.d.). search.ligazakon.ua.Retrievedfrom http://search.ligazakon.ua/1_doc2.nsf/link1/GH57B00A.html [in Ukrainian].

7. Golkovanov, K. (Ed.). (2011). Rozvytok mizhmunitsypal'noho spivrobitnytstva: vitchyznyanyy ta zarubizhnyy dosvid [Development of inter-municipal cooperation: domestic and foreign experience]. Kramar [in Ukrainian].

8. Stepanenko, A.V., Onishchenko, A.A. (2019). Mis'ki ahlomeratsiyi, yak formy suchasnoho svitovoho protsesu hlobalizatsiyi [Urban agglomerations as forms of the modern world process of globalization]. Seriya "Ekonomika ta pidpryyemnytstvo"- Economy and Entrepreneurship series, 3, [in Ukrainian].

9. Shemshuchenko, Yu.S. (Ed.). (1999). Yurydychna entsyklopediya [Legal Encyclopedia]. (T. 2). Kyiv: Ukr. entsyklopediya. [in Ukrainian].

10. Pavlov K., Pavlova O. \& Kupchak V. (2019). Integral Indicators Based on Competitiveness Capacity Characteristics of Regional Real Estate Markets of Ukraine. Journal of Competitiveness. №11(3). 87-108. https://doi.org/10.7441/joc.2019.03.06. 